\title{
Brazilian translation, cross-cultural adaptation and validation of the Myasthenia Gravis Composite scale and Quantitative Myasthenia gravis testing form: a multicentric study protocol.
}

\author{
Tradução, adaptação cultural e validação da escala Composta Miastenia \\ Gravis e do teste Quantitativo Miastenia Gravis para a lingua portuguesa \\ do Brasil: protocolo de estudo multicêntrico.
}

Ezequiel Fernandes de Oliveira', Jessica Julioti Urbano', Israel Reis Santos'1, Anderson Soares Silva', Letícia Lopes Guimarães', Roger André Oliveira Peixoto', Eduardo Araújo Perez², Paulo Cesar Bosio³, Melissa Nunes Polaro ${ }^{4}$, Berenice Cataldo Oliveira Valério ${ }^{4}$, Roberto Stirbulov², João R Pereiro ${ }^{5}$, Sergio Roberto Nacif5, Valéria Cavalcante ${ }^{6}$, Acary Souza Bulle Oliveira $^{6}$, Claudia Santos Oliveira', Luis Vicente Franco de Oliveira ${ }^{1}$

\begin{abstract}
Introduction: Myasthenia gravis (MG) is a chronic and inflammatory disease characterized by progressive weakness of the skeletal muscles due to changes in the synaptic junctions between nerves and muscle fibres. Typically, patients have a history of progressive weakness and fatigue in skeletal muscles, which occurs during sustained or repeated activities and improves after rest. Scoring systems to assess the degree of disease severity are commonly used in clinical drug trials. Further, specific instruments to assess health-related quality of life (HRQOL) have been designed to measure self-perception of symptoms and wellness during the disease or after disease treatment. HRQOL is an important component of patient evaluation, as some individuals can tolerate severe impairment and disability, while others may be very unhappy even with less severe symptom profiles. The objective of the proposed study is to translate and perform a cultural adaptation and validation of two specific instruments for assessing the clinical course of patients with MG. These instruments include the Quantitative Test for Myasthenia gravis (QMG) and Myasthenia gravis Composite Scale (MGC). Methods and analyses: The study design will follow a multi-method approach, and will be conducted in three stages consisting of translation, cultural adaptation, and validation of the QMG and MGC for Brazilian Portuguese patients. This multi-step process will consider aspects of construct and predictive validity as well as reliability and structure of the instrument. The entire process will follow the procedures proposed and developed in other linguistic and social-cultural contexts based on previous studies. Ethics: This study has received approval from the Human Research Ethics Committee of Nove de Julho University (Brazil) under process no. 360.488 based on the Helsinki declaration and is registered with the World Health Organization (WHO) under Universal Trial Number (UTN) U1111-1147-7853 and the Brazilian Registry of Clinical Trials (REBEC) RBR -7ckpdd.
\end{abstract}

Keywords: Myasthenia Gravis, translation, cross-cultural adaptation, validation, Myasthenia Gravis Composite scale, Quantitative Myasthenia gravis testing form, quality of life.

\footnotetext{
Corresponding author: Luis Vicente Franco Oliveira. Rua Itapicuru, 380 - apto 111, Perdizes, Zip Code: 05006-000, São Paulo (SP), Brazil. E-mail: oliveira.lvf@uninove.br ${ }^{1}$ Universidade Nove de Julho (UNINOVE), São Paulo (SP) Brazil.
}

Full list of author information is available at the end of the article.

Financial support: Fundação de Amparo a Pesquisa do Estado de São Paulo (FAPESP), Conselho Nacional de Desenvolvimento Cientifico e Tecnologico (CNPq).

Submission date 30 November 2015; Acceptance date 08 February 2016; Publication date 24 February 2016 


\section{RESUMO}

Introdução: A Miastenia Gravis (MG) é uma doença crônica e inflamatória caracterizada por fraqueza progressiva dos músculos esqueléticos, devido a alterações nas junções sinápticas entre nervos e fibras musculares. Os pacientes apresentam uma história de fraqueza progressiva e fadiga nos músculos esqueléticos, que ocorre durante as atividades sustentadas ou repetidas e melhora após o descanso. Sistemas de pontuação para avaliar o grau de gravidade da doença são comumente usados em ensaios clínicos de drogas. Além disso, instrumentos específicos para avaliar a qualidade de vida relacionada a saúde (QVRS) foram concebidos para medir a auto percepção de sintomas e de bem-estar durante a doença ou após o tratamento da doença. QVRS é um componente importante da avaliação do paciente, como algumas pessoas podem tolerar comprometimento grave e incapacidade, enquanto outros não toleram o mesmo perfil de sintomas. O objetivo é traduzir e realizar uma adaptação cultural e validação de dois instrumentos específicos para avaliar a evolução clínica de pacientes com MG. Estes instrumentos incluem o teste quantitativo para Miastenia gravis (QMG) e a escala composta Miastenia gravis (MGC). Analises e método: O desenho do estudo seguirá uma abordagem multimétodo, e será realizado em três etapas que consistem em tradução, adaptação cultural e validação da QMG e MGC para o português brasileiro. Este processo multipasso irá considerar aspectos de construção e validade, bem como confiabilidade e estrutura dos instrumentos. Todo o processo seguirá os procedimentos propostos e desenvolvidos em outros contextos linguístico e sociocultural com base em estudos anteriores. Ética: Este estudo recebeu aprovação do Comitê de Ética em Pesquisa com Seres Humanos da Universidade Nove de Julho (Brasil) sob processo no. 360.488 baseada na Declaração de Helsinki e está registrada na Organização Mundial de Saúde (OMS), sob Universal Trial Number (UTN) U1111-1147-7853 e o Registro Brasileiro de Ensaios Clínicos (REBEC) RBR -7ckpdd.

Palavras-chave: Miastenia Gravis, tradução, adaptação cultural, validação, escala composta para Miastenia Gravis, teste quantitativo para Miastenia gravis, qualidade de vida.

\section{INTRODUCTION}

Myasthenia gravis (MG) is a chronic autoimmune disease caused by antibodies against the acetylcholine receptors (AchR) on the post-synaptic membrane of the neuromuscular junction. This disease is characterized by progressive weakness and fatigue of skeletal muscles. ${ }^{(1,2)}$ Its annual incidence is 1-15 cases per million; the disease occurs in individuals between ages 20 and 40 years with females being more affected than men (ratio of $3: 2$ ). ${ }^{(3,4)}$

The disease severity depends on the muscle groups affected and can range from mild, with purely ocular symptoms, to more severe cases with generalized muscle weakness and respiratory failure. ${ }^{(1)}$ The Committee of the Myasthenia Gravis Foundation of America (MGFA) classified MG into five levels of severity based on the onset of symptoms and anatomical distribution in muscles groups. ${ }^{(5)}$

In recent years, there have been significant advances in the diagnosis and treatment of MG, which was traditionally considered a disabling and often fatal condition, justifying the name "gravis." Prior to the 1960s, the mortality rate for MG was approximately $30 \%$, despite treatment. This mortality rate has been practically reduced to 0 with current therapies, which have been highly effective. ${ }^{(6)}$ Modern immunotherapy has considerably improved prognosis and most patients lead a complete and productive life. However, despite advances in treatment, we may observe a shortage of database information. Some clinical scoring systems for assessing the degree of disease severity are currently used in clinical trials of new drugs. (7-10)

Specific instruments designed to assess health-related quality of life (HRQOL) measure self-perception of symptoms and wellness related to a disease or treatment. ${ }^{(11)} \mathrm{HRQOL}$ is an important component in patient evaluation, given that individuals have different reactions to their diagnosis. These assessment tools can be used generally for a group of diseases or for a specific disease, such as MG. ${ }^{(12)}$

Previous studies have described a correlation between HRQOL and severity of MG. ${ }^{(13-15)}$ Information regarding the HRQOL obtained from patients may influence treatment decisions and provide a better understanding of their needs, providing an adequate clinical support. ${ }^{(16)}$ The more specific the instrument, the more relevant it becomes for evaluation and follow-up.

Based on our review of the international scientific literature, four specific instruments for MG were found including two on HRQOL and two on disease severity. Of these instruments, only the Questionnaire of Life Quality Specific for Myasthenia Gravis-15 items has been translated into Portuguese for use in Brazil. Therefore, there is need for a study aimed at the translation and validation of additional instruments for assessing the clinical course and severity of MG in Portuguese-speaking patients.

The objective of this study is to translate and perform the cultural adaptation and validation of two specific instruments designed to assess the clinical course in MG. The selected instruments include the Quantitative Test for Myasthenia gravis (MGQ) and the Myasthenia gravis Composite Scale (MG Composite). We believe that these revised instruments can contribute to patient evaluation in the clinical setting and in research, providing reliable insights into the physical well-being and clinical course of Brazilian patients with MG.

\section{METHODS}

The study will be conducted in accordance with the ethical standards established in the 1961 Declaration of Helsinki (as revised in Hong Kong in 1989 and Edinburgh, Scotland in 2000) 
and will comply with the Regulatory Guidelines and Norms for Research Involving Human Subjects of the National Health Board of the Brazilian Health Ministry issued in October 1996.

This study has been approved by the Human Research Ethics Committee of Nove de Julho University (Brazil) under process no. 360.488 and is registered with the World Health Organization (WHO) under Universal Trial Number (UTN) U1111-1147-7853 and the Brazilian Registry of Clinical Trials (REBEC) RBR -7ckpdd. A written informed consent will be obtained, and subjects will be allowed to withdraw from the study at any time with no negative consequences.

The study design will follow a multi-method approach and will be conducted in three stages consisting of translation, cultural adaptation, and validation of the MGQ and MG Composite. Construct and predictive validity and aspects of reliability and structure of the instrument will be considered.

\section{Instruments}

The QMG scale was developed by Besinger as an outcome of a clinical trial and assesses disease severity. ${ }^{(16)}$ Initially, this scale consisted of 8 stratified items on a scale from 0 to 3, where 3 indicated greater severity. In 1992, Tindal et al. modified this scale to include 13 items based on two studies investigating the efficacy of cyclosporine drug therapy in MG. This study showed a significant reduction in the average score on the MGQ for the therapy group compared to the placebo group. ${ }^{(7,8)}$ Barohn et al. (1998) performed inter-rater reliability testing using the modified MGQ scale by Tindal et al. in order to determine the scale's reliability and the number of patients needed to perform a randomized clinical trial. Three parameters in the previous version of the scale that could not be easily quantified (facial muscles, chewing, and swallowing) were modified. ${ }^{(17)}$ Since this study, the MGQ has been widely used in several clinical trials involving patients with MG. This measure is easily administered in approximately 30 minutes and requires minimal equipment.

The MGC is a valid and reliable instrument used to assess the clinical condition of patients with MG both in clinical practice and in scientific research. This scale was validated in clinical studies conducted in 2008 and 2009 in 11 research centres specializing in the care of neuromuscular diseases; 9 centres were in the US and two were in Europe. ${ }^{(18,19)}$

The MG Composite is an ordinal scale consisting of 10 items, each representing a feature commonly experienced with MG. The response categories of the scale items are weighted. For example, the ptosis item equals 3 points, the item 'severe weakness in hip flexion' is 5 points, and 'severe respiratory weakness' (i.e., ventilator dependency) is 9 points. The maximum score on the scale is 50 points and a higher score is indicative of a more severe clinical condition. Burns and colleagues investigated the validity and reliability of this scale and found that an improvement of 3 points indicates a significant clinical improvement in patients with MG. ${ }^{(19)}$

\section{Translation, cross-cultural adaptation, and validation}

The process of translation, cultural adaptation, and validation of the QMG and MGC will follow the procedures proposed and developed in other linguistic and social-cultural contexts. ${ }^{(20-24)}$ Figure 1 shows the flowchart of the translation and adaptation process.

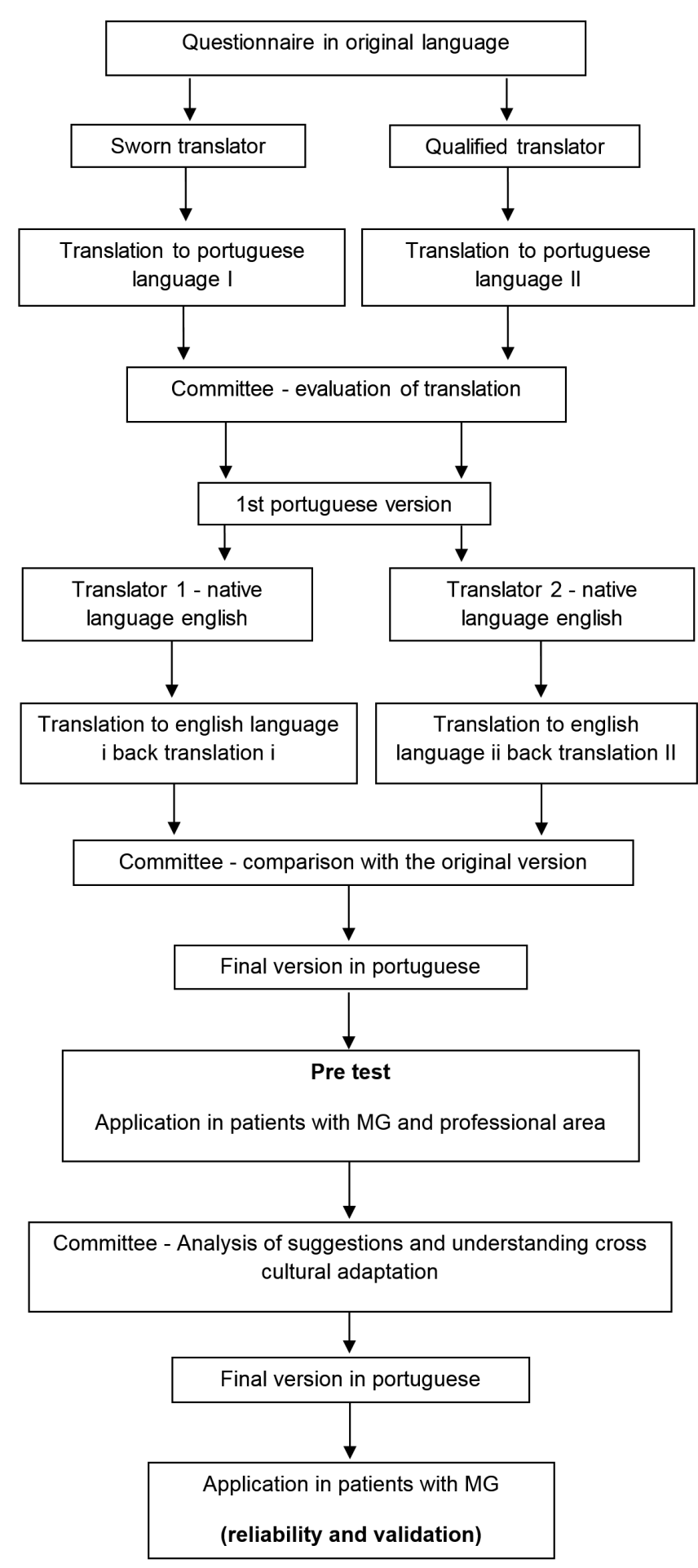

Figure 1. Flowchart of the study. 


\section{Translation}

According to the established protocol, two qualified Brazilian translators, one sworn translator who is unfamiliar with the knowledge area and another bilingual neurologist, will translate the QMG and MGC into Brazilian Portuguese.

Next, a committee of four neurologists and two physiotherapists, all bilingual, will compare these two translated versions, creating the first version of the scales in Portuguese. All members of this committee will be bilingual university professors and researchers with clinical experience in neuromuscular diseases and advanced knowledge of the English language.

\section{Back translation}

Two native English Language, being one a professional translator, layman and the other one a neurologist, will perform the back-translation of the first version of the scales in Portuguese (Brazil). Translators will not be informed about the study objectives and will have no access to the original version. The expert committee will compare the back-translation with the original version, making the necessary adjustments, generating the second version in Portuguese. The final version of the scales in Portuguese will be established after consensus among committee members on each item.

\section{Cross-cultural adaptation (Pre-test)}

The final versions of the scales will undergo semantic analysis to determine whether the terms used are clear. To ensure that the translated measures are equivalent to the originals, they will be checked by a pre-test, which includes assessing the degree of understanding of the proposed questions.

This pre-test will involve administering the items to 20 patients with MG and 12 professionals specialized in the area of clinical neurology. The pre-test results will be used to determine the level of semantic understanding in order to consolidate the final versions that will be used in the test phase as described below.

\section{Validation}

Seventy-five patients aged $18-50$ years who have been diagnosed with MG defined and classified according to MGFA will be invited to participate in this study. Participants will be screened by the Neuromuscular Diseases Research Division of the Federal University of São Paulo, UNIFESP; Department of Internal Medicine of Neurology, School of Medical Sciences of Santa Casa de São Paulo, FCMSC; and the Department of Neurology, Hospital for State Public Server, HSPE. The following data will be collected from the patients' records: demographic and clinical data, age, sex, weight, height, marital status, education level, current symptoms of MG, and therapeutic strategies used. The exclusion criteria will include cognitive impairment, illiteracy, and other chronic diseases.
The newly translated versions of MGQ and MG Composite will be compared to the Quality of Life Questionnaire for Specific Myasthenia Gravis.15 items (MG-QOL-15), which has been previously validated in Brazil and is considered to be the gold standard for assessing quality of life in MG.

The MG-QOL15 is a specific instrument that assesses HRQOL in patients with MG. This scale consists of 60 items and is effective, fast, and easy to perform. Each item is scored from 0 to 4 and evaluates the frequency for each item. The maximum score is 60 points with higher scores indicating worse perceived quality of life by the patient. MG-QOL15 has at least three possible functions. The first is that it assesses the perceived level of dysfunction and degree of satisfaction or dissatisfaction with the disease. The second function is evaluation of disease course and, perhaps, determination of treatment efficacy. The third function is monitoring the aggregate HRQOL for groups of patients in order to determine treatment effectiveness. On a scale of 0-60, the higher the score, the worse the patient's condition. The instrument does not have a determined cut-off value. ${ }^{(9,25)}$

\section{Statistical Analysis}

The Kolmogorov-smirnov test will be used for numeric variables to test normality. Data will be reported as mean \pm standard deviation (SD) unless otherwise specified. The level of significance for all tests was set at $p<0.05$. Reliability will be determined by analyzing test-retest reproducibility, internal consistency and the coefficient of variation. Test-retest reproducibility will be assessed by computing the coefficient of variation between MGC and QMG scores after retesting (Wilcoxon signed rank test) and expressing the proportion of the variance of one set of results explained by the other using the square of Pearson's correlation $\left(r^{2}\right)$. Internal consistency will be measured by calculating Cronbach's $\alpha$ reliability coefficient for the both scales. Statistical analyses was performed with the Statview 5.0 (SAS Institute, Cary, N.C., USA), and SPSS software (version 16.0, SPSS Inc. Chicago, IL, USA)

\section{Description of risks}

There will be no risks for included patients.

\section{Ethical and legal aspects}

The study will be conducted in accordance with the ethical standards laid down in the 1961 Declaration of Helsinki (revised Hong Kong in 1989 and Edinburgh, Scotland, in 2000) and will be in accordance with the Regulatory Guidelines and Standards Research Involving Human Subjects of Comissão nacional de ética em pesquisa (CONEP) do ministerio da saude published in December 2012. This study protocol has been approved by the Research Ethics Committee of the University Nove (Brazil), in case no. 360.488 and is registered in the World Health Organization (WHO) as Universal Trial Number (UTN) 
U1111-1147-7853 and the Brazilian Registry of Clinical Trials (Rebec) RBR -7ckpdd.

The signing of the free and informed consent (IC) will be required, and patients will be allowed to withdraw from the study at any time without negative consequences. All procedures in this study are confidential and reflect the typical nature of the therapist/patient relationship. Patients with severe clinical problems will be referred to the appropriate treatment aimed at their health status and quality of life.

\section{ACKNOWLEDGEMENT}

The Sleep Laboratory receives funding from the Nove de Julho University (Brazil) and research projects approved by the Brazilian fostering agencies Fundaçao de Amparo a Pesquisa do Estado de Sao Paulo (local acronym FAPESP; protocol no. 2003/01810-4) and LVFO receive Research Productivity modality IB grants by Conselho Nacional de Desenvolvimento Cientifico e Tecnologico (local acronym CNPq; process no. 313053/2014-6). EFO receive grants of Fundaçao de Amparo a Pesquisa do Estado de Sao Paulo (local acronym FAPESP; protocol no. 2015/11738-6).

\section{AUTHOR'S CONTRIBUTION}

LVFO, ASBO, CSO and EFO provided the concept of the study, created the hypothesis, and wrote the original proposal. EFO, ASBO, RS, BCOV, PCB, JRP and LVFO significantly contributed to the writing of this proposal. JJU, EAP, PCB, IRS, LLG, VC, ASS, MNP, SRN, and LVFO were involved in the critical revision of the manuscript. EFO, ASBO, CSO and LVFO wrote this protocol paper, with input from all co-authors. All the authors read and approved the final manuscript.

COMPETING INTERESTS

The author(s) declare that they have no competing interests.

\section{AUTHOR DETAILS}

2 Faculdade de Ciências Médicas da Santa Casa de São Paulo (FCMSCSP), São Paulo (SP) Brazil. 3. Physical Therapy School, Centro Universitário Barão de Mauá, Ribeirão Preto (SP) Brazil. 4. Department of Medical Clinic, Faculdade de Ciências Médicas da Santa Casa de São Paulo (FCMSCSP), São Paulo (SP) Brazil. 5. Hospital Servidor Público Estadual (HSPE), São Paulo (SP) Brazil. 6. Division of Neuromuscular Disorders, Department of Neurology and Neurosurgery, Universidade Federal de São Paulo (UNIFESP), Sao Paulo (SP) Brazil.

\section{REFERENCES}

1. Drachman D. Myasthenia gravis. In: Rose N, Mackay I. The autoimmune diseases. 3rd ed. San Diego: Academic Press, 1998:637-62.

2. Tzartos SJ, Barkas T, Cung MT, Mamalaki A, Marraud M, Orlewski P, et al. Anatomy of the antigenic structure of a large membrane autoantigen, the muscle-type nicotinic acetylcholine receptor. Immunol Rev. 1998;163:89120.

3. Carr AS, Cardwell CR, McCarron PO, McConville J. A systematic review of population based epidemiological studies in Myasthenia Gravis. BMC Neurology. 2010;10:1-9.

4. Mao ZF, Mo XA, Qin C, Lai YR, Hartman TC. Course and prognosis of myasthenia gravis: a systematic review. Eur J Neurol. 2010;17:913-921.

5. Jaretzki A 3rd, Barohn RJ, Ernstoff RM, Kaminski HJ, Keesey JC, Penn AS, et al. Myasthenia gravis: recommendations for clinical research standards. Task Force of the Medical Scientific Advisory Board of the Myasthenia Gravis Foundation of America. Neurology. 2000;55(1):16-23.
6. AAM Quality Assurance Committee. Literature review of the usefulness of repetitive nerve stimulation and single fiber EMG in the electrodiagnostic evaluation of patients with suspected myasthenia gravis or Lambert-Eaton myasthenic syndrome. Muscle Nerve. 2001;24(9):1239-1247.

7. Tindall RS, Rollins JA, Phillips JT, Greenlee RG, Wells L, Belendiuk G. Preliminary results of a double-blind, randomized, placebo controlled trial of cyclosporine in myasthenia gravis. N Engl J Med. 1987;316(12):719-24.

8. Tindall RS, Phillips JT, Rollins JA, Wells L, Hall K. A clinical therapeutic trial of cyclosporine in myasthenia gravis. Ann N Y Acad Sci. 1993;681:539-51.

9. Burns TM1, Grouse CK, Conaway MR, Sanders DB; mg composite and mg-qol15 study group. Construct and concurrent validation of tha MGQOL15 in the practice setting. Muscle Nerve. 2010;41(2):219-226.

10. Burns TM1, Conaway M, Sanders DB; MG Composite and MG-QOL15 Study Group. The MG Composite. A valid and reliable outcome measure for myasthenia gravis. Neurology. 2010;74(18):1434-1440.

11. Ebrahim S. Clinical and public health perspectives and applications of health-related quality of life measurement. Soc Sci Med. 1995;41:13831394.

12. Cella DF, Tulsky DS. Measuring quality of life today: methodological aspects. Oncology. 1990;4:29-38.

13. Raggi A, Leonardi M, Antozzi C, Confalonieri P, Maggi L, Cornelio F, et al. Concordance between severity of disease, disability and health-related quality of life in Myasthenia gravis. Neurol Sci. 2010;31:41-45.

14. Leonardi M, Raggi A, Antozzi C, Confalonieri P, Maggi L, Cornelio F, et al. The relationship between health, disability and quality of life in myasthenia gravis: results from an Italian study. J Neurol. 2010;257:98-102.

15. Morris J, Perez D, McNoe B. The use of quality of life data in clinical practice. Qual Life Res. 1998;7:85-91.

16. Besinger UA, Toyka KV, Homberg M, Heininger $K$, Hohlfeld R, FatehMoghadam A. Myasthenia gravis: long-term correlation of binding and bungarotoxin blocking antibodies against acetylcholine receptors with changes in disease severity. Neurology. 1983;33(10):1316-21.

17. Barohn RJ, Mclntire D, Herbelin L, Wolfe GI, Nations S, Bryan WW. Reliability testing of the quantitative myasthenia gravis score. Ann N Y Acad Sci. 1998;841:769-72.

18. Burns TM, Conaway MR, Cutter GR, Sanders DB. The construction of an efficient evaluative instrument for Myasthenia gravis: the MG Composite. Muscle Nerve. 2008;38:1553-1562.

19. Burns TM, Conaway MR, Sanders DB, and the MG Composite and MGQOL15 Study Group. The MG Composite: a valid and reliable tool for myasthenia gravis. Neurology. 2010;74:1434-1440.

20. Guillemin F, Bombardier C, Beaton D. Cross-cultural adaptation of healthrelated quality of life measures: literature review and proposed guidelines. J Clin Epidemiol.1993;46(12):1417-32.

21. Guillemin F. Cross-cultural adaptation and validation of health status measures. Scand J Rheumatol. 1995;24(2):61-3.

22. Reichenheim M, Moraes $C$. Operacionalização de adaptação transcultural de instrumentos de aferição usados em epidemiologia. Rev Saúde Pública. 2007;41(4):665-73.

23. Maher C, Latmer J, Costa L. The relevance of cross-cultural adaptation and clinimetrics for physical therapy instruments. Rev Bras Fisioter. 2007;11(4):245-52.

24. Beaton D, Bombardier C, Guillemin F, Ferraz M. Guidelines for process of cross-cultural adaptation of selfreport measures. Spine. 2000;(25)24:3186-91.

25. Mourão AM, Araújo CM, Barbosa LSM, Gomez RS, Burns TM, Lemos SMA, et al. Brazilian cross-cultural translation and adaptation of the "Questionnaire of Life Quality Specific for Myasthenia Gravis. 15items". Arq. Neuro-Psiquiatr. 2013 Dec; 71(12):955-958. 